\title{
Spatial Analysis of Forest Fragmentation in the Atlantic Forest Bioma Areas
}

\author{
Juliana Marchesan ${ }^{1}$, Rudiney Soares Pereira ${ }^{1}$, Elisiane Alba ${ }^{1} \&$ Letícia Daiane Pedrali ${ }^{2}$ \\ ${ }^{1}$ Federal University of Santa Maria, Santa Maria, Brazil \\ ${ }^{2}$ Polytechnic College of the Federal University of Santa Maria, Santa Maria, Brazil \\ Correspondence: Juliana Marchesan, Federal University of Santa Maria, Rio Grande do Sul, Brazil, Santa Maria, \\ 97105-900, Brazil. Tel: 55-55-99646-2129. E-mail: marchesan.ju@gmail.com
}

Received: August 17, 2018

doi:10.5539/jas.v10n12p294

\author{
Accepted: September 20, $2018 \quad$ Online Published: November 15, 2018 \\ URL: https://doi.org/10.5539/jas.v10n12p294
}

\begin{abstract}
The goal of this work was to calculate landscape ecology metrics using the R language, allowing the analysis of forest fragments under the Atlantic Forest domain located in the sub-basin of Arroio Jaquirana, Rio Grande do Sul, Brazil. For the mapping of the forest fragments, we used images from the REIS/RapidEye sensor dated 2016, and the classification was supervised through the Bhattacharya algorithm. The fragments were analyzed in seven size classes, to separate them and to calculate the landscape metrics it was used $\mathrm{R}$ language. The results attained demonstrated that the native forest occupied $34.01 \%$ of the study area, covering a total of 1,995 fragments, of which $93.43 \%$ were less than 5 ha. The highest values of edge and perimeter-area ratio were found in the small fragments indicating a greater edge effect, with the central areas of these remnants being exposed to the external matrix effects. Thus, it is concluded that the Atlantic Forest is highly fragmented and is extremely important to establish measures to minimize the effects and/or increase the connectivity between the fragments through ecological corridors using the smaller fragments, in addition, it makes necessary the development of public policies and research for the management of the region in order to preserve the remnants.
\end{abstract}

Keywords: landscape ecology metrics, deforestation, remote sensing, $R$ language

\section{Introduction}

For decades the deforestation resulting from the process of anthropization of the landscape, has caused the destruction of natural resources. Native forests gave way mainly to agriculture, livestock and urbanization, with the formation of fragments, often isolated from one another. The loss of areas, the increasing of the isolation and the greater exposure of the borders of the fragments to human actions cause changes in the structure and function of these fragments (Lindenmayer \& Fischer, 2006).

The process of forest fragmentation and loss of areas are present in the different biomes. However, the Atlantic Forest is one of the most threatened biomes in the world, being one of the most deforested (Jenkins et al., 2013). Thus, this biome was conferred the title of hotspots due to it being a threatened area, yet rich in biodiversity (Laurance, 2009). Originally the forest area covered approximately $1,315,460 \mathrm{~km}^{2}$, and currently there are only $12.5 \%$ of this original area, when the fragments above 3 hectares were recorded (SOS Mata Atlântica, 2015). In addition, it is highly fragmented, with $83 \%$ of the fragments smaller than 50 ha (Ribeiro, Metzger, Martensen, Ponzoni, \& Hirota, 2009), being the conservation of the remaining remnants primordial.

Thus, it is necessary to carry out studies related to the spatial characterization of forest fragments in order to establish conservation strategies (Pirovani et al., 2014). In this context, the ecology of the landscape is inserted, since the search for ecological knowledge about the forest fragments of a given area allows applying a correct environmental management as to these forests management (Calegari, Martins, Gleriani, Silva, \& Busato, 2010; Negrini et al., 2014). In landscape ecology, the main object to be measured is the landscape structure, which provides characteristics of the constituent elements of the landscape, being commonly expressed through landscape metrics (Skokanová \& Eremiášová, 2013). The landscape metrics contribute to the maintenance of biodiversity, since the analysis of these contributes to the determination of management techniques with the purpose of conserving and recovering the remaining forest fragments (Juvanhol et al., 2011). Thus, to evaluate 
the landscape becomes important to verify the current problems, to estimate the future ones and to point out the necessary measures to maintain the balance of the ecosystem (Calegari et al., 2010).

Thus, analyzing forest fragmentation is important due to its impacts caused to the environment. According to Matos et al. (2017), the fragmentation process causes changes in forest structure and biodiversity. The main consequences of habitat loss, species isolation, edge effects, invasion of exotic species, decrease of biodiversity, decrease of pollination and consequently disappearance of species (Silva, Metzger, Simões, \& Simonetti, 2007; Lindenmayer et al., 2008; Calegari et al., 2010). Thus, in general, the fragmentation process changes the dynamics of populations and communities, ecosystem processes and trophic interactions (Laurance \& Vasconcelos, 2009).

Mariota (2015) report that a challenge of the present day is to reliably and economically monitor landscape dynamics in order to implement effective conservation strategies. In this context, several metrics have been used to describe spatial patterns through the use of remote sensing and geoprocessing tools (Jung, 2016), since they provide detection of remnants that present potential for conservation in a fast and accurate way (Silva et al., 2015). These tools are the Geographic Information Systems (GIS).

At present, there are several GIS for manipulation of data from remote sensors, some of them used for analysis of fragmentation, in which they perform calculations of landscape ecology metrics. Recently, researchers have been using the $\mathrm{R}$ language for spatial data analysis. The $\mathrm{R}$ has several advantages that makes it a promising tool in the area of remote sensing and geoprocessing, since it is free, flexible in the type of data that can be analyzed, it allows changes in available functions and is compatible with all platforms (Muenchen, 2011). Due to these characteristics, $\mathrm{R}$ is a complete and extremely powerful programming language (Casajus, 2013).

The study was directed to the hydrographic sub-basin of Arroio Jaquirana, Rio Grande do Sul, due to it is located in areas of the Atlantic Forest biome, characterized by intense agricultural activity with high rates of deforestation and, consequently, presenting itself in an advanced process of fragmentation. Therefore, it was considered important to analyze the landscape structure mentioned in order to understand its behavior before the use of landscape metrics and with that serve as a basis for planning the region in order to recover or preserve the remaining forest remnants. In this context, the present study aimed to calculate landscape ecology metrics using the $\mathrm{R}$ language, allowing the analysis of forest fragments under the domain of the Atlantic Forest biome located in the sub-basin of Arroio Jaquirana, Rio Grande do Sul, Brazil.

\section{Method}

\subsection{Location and Characterization of the Study Area}

The study area consists on the sub-basin of Arroio Jaquirana, which covers the municipalities of Arroio do Tigre, Lagoão, Segredo, Sobradinho and Passa Sete, located in the State of Rio Grande do Sul, Brazil (Figure 1). The total area of the sub-basin is approximately 41,460 ha.

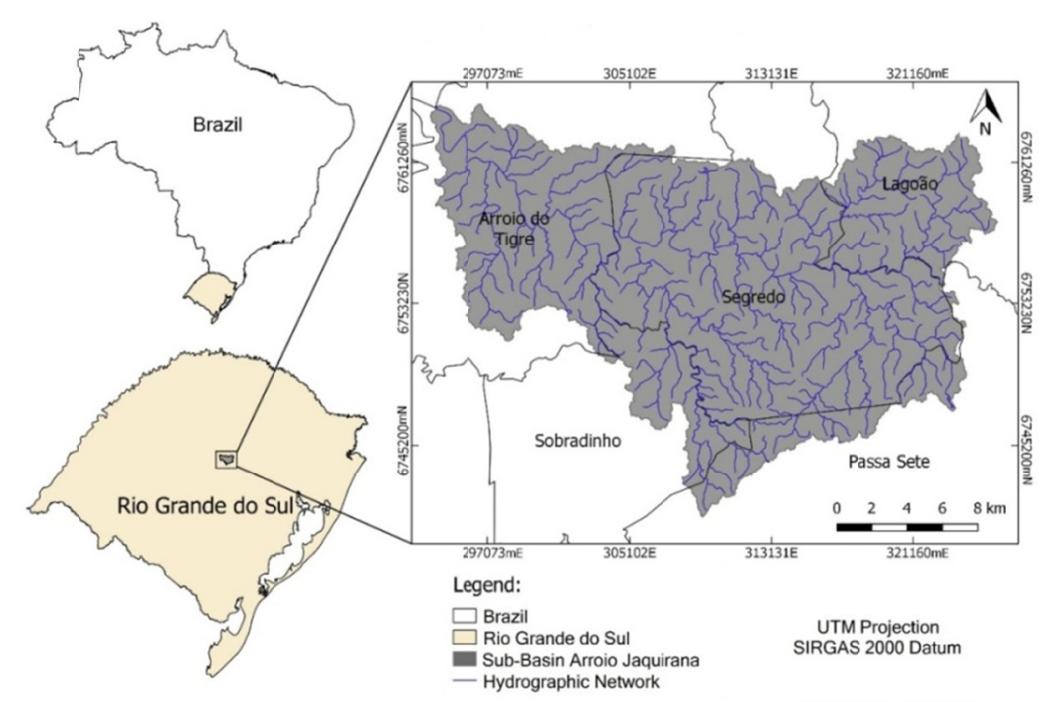

Figure 1. Location of the hydrographic sub-basin of Arroio Jaquirana, Rio Grande do Sul, Brazil 
The sub-basin of Arroio Jaquirana is an affluent of the Jacuizinho River, which, in turn, flows into the Jacuí River, thus, is inserted in the catchment area of Alto Jacuí. The main phytogeographic type is the Decidual Seasonal Forest, belonging to the Atlantic Forest biome, limiting the pastures of the southern campaign and the northern plateau (Rambo, 1956). According to the classification of Köppen the climate is a Humid Subtropical (Cfa), with average temperatures that vary between $16{ }^{\circ} \mathrm{C}$ and $20^{\circ} \mathrm{C}$. The precipitations are well distributed throughout the year, varying between 1,600 and 1,900 mm (Alvares, Stape, Sentelhas, Gonçalves, \& Sparovek, 2014).

\subsection{Mapping of Forest Fragments}

Two SRTM (Shuttle Radar Topography Mission) scenes, captured by the Space Shuttle Endeavor, with a $30 \mathrm{~m}$ spatial resolution, were available for free from the USGS (United States Geological Survey). The area was automatically delimited using the GRASS modules version 7.0.4, coupled with the QGis software - Quantum GIS Geographic Information System (QGIS Development Team, 2016), version 2.14.7.

In the SPRING-Georeferenced Information Processing System, version 5.2.7 (Câmara, Souza, Freitas, Garrido, \& Mitsuo, 1996), a spatial database with UTM (Universal Tranverse Mercator) and Datum SIRGAS 2000 cartography was created. For the mapping of the fragments of native forest four scenes REIS (RapidEye Earth Imaging System) sensors were needed, RapidEye satellite, with a resolution of 5 meters, composed of 5 multispectral bands, dated February 29, 2016. They were obtained by means of a project between the Federal University of Santa Maria and the Interstate Union of the Tobacco Industry (SINDITABACO), which aims to monitor forest cover in areas of Deciduous Seasonal Forest in the Central Sierra region of Rio Grande do Sul state.

Among the techniques of segmentation, this process precedes the classification, it was chosen the region's growth method, which consists of aggregating neighboring pixels to a given region that presents similar characteristics, thus occurring the increase of these regions (Happ, Feitosa, Bentes, \& Farias, 2013). For this, it was necessary to define the parameters of similarity and area, being used the values of 10 and 100 , since they were better suited to the study area. The classification was performed in a supervised manner using the Bhattacharya algorithm with a $99 \%$ acceptance threshold. With this algorithm the Bhattacharya distance measure is used to calculate the statistical separability between pairs of spectral classes, thus measuring the average distance between the probability distributions of the classes (Brites, Bias, \& Rosa, 2012).

The efficiency of the mapping was verified using the Kappa index proposed by Congalton and Green (1999), according to Equation 1, and the quality of the generated data was evaluated according to the limits proposed by Landis and Koch (1977), according to Table 1.

$$
\mathrm{K}=\frac{\mathrm{N} \cdot \sum_{\mathrm{i}=1}^{\mathrm{r}} \mathrm{X}_{\mathrm{ij}}-\sum_{\mathrm{i}=1}^{\mathrm{r}} \mathrm{X}_{\mathrm{i}+} \cdot \mathrm{X}_{+\mathrm{i}}}{\mathrm{N}^{2}-\sum_{\mathrm{i}=1}^{\mathrm{r}} \mathrm{X}_{\mathrm{i}+} \cdot \mathrm{X}_{+\mathrm{i}}}
$$

Where, $r=$ number of classes; $X_{i j}=$ number of elements sorted correctly; $X_{i^{+}}=$total of elements classified for a category $\mathrm{i} ; \mathrm{X}_{+\mathrm{i}}=$ total of reference elements sampled for a category $\mathrm{I} ; \mathrm{N}=$ total number of samples.

Table 1. Quality of the classification according to Kappa coefficient intervals

\begin{tabular}{ll}
\hline Kappa value & Quality of classification \\
\hline$<0.00$ & Very bad \\
$0.0-0.20$ & Bad \\
$0.20-0.40$ & Acceptable \\
$0.40-0.60$ & Good \\
$0.60-0.80$ & Very good \\
$0.80-1.00$ & Excellent \\
\hline
\end{tabular}

Source: Landis and Koch (1977).

In order to carry out the calculations, 200 points were distributed over the forest theme class, in a stratified random manner, according to Congalton's (1991) methodology, which suggested a minimum size of 50 samples for each category in areas that have a territorial coverage of up to approximately $4,050 \mathrm{Km}^{2}$. To verify the veracity of the classification we used high spatial resolution images of Google Earth Pro (Moreira, Barros, \& Rudorff, 2008). 


\subsection{Analysis of Forest Fragmentation}

The raster file containing the forest fragments was imported into the development environment integrated with the $\mathrm{R}$ version 3.3.0 (R Development Core Team, 2016), for splitting the fragments into size classes, in which a sequence of commands in $\mathrm{R}$ language was employed. The fragments were grouped in adapted classes of Ribeiro et al. (2009), in order to compare the different sizes in the study area (Table 2).

Table 2. Size classes of forest fragments adopted for analysis of landscape ecology metrics

\begin{tabular}{ll}
\hline Size class & Size of the fragments (ha) \\
\hline 1 & $<5$ \\
2 & $5 \vdash-50$ \\
3 & $50-100$ \\
4 & $100-250$ \\
5 & $250-500$ \\
6 & $500-1,000$ \\
7 & $\geq 1,000$ \\
8 & 0 to $\geq 1,000$ \\
\hline
\end{tabular}

In order to avoid the use of redundant metrics, they encompassed different groups: area and density, edge, shape, central area and proximity. As shown in Table 3.

Table 3. Landscape ecology metrics used in the study

\begin{tabular}{|c|c|c|c|}
\hline Group & Initials & Landscape Metrics & Unity \\
\hline \multirow[t]{6}{*}{ Area and density } & $\mathrm{CA}$ & Class Area & ha \\
\hline & NP & Number of Patches & - \\
\hline & MPS & Mean Patch Size & ha \\
\hline & MedPS & Median Patch Size & ha \\
\hline & PSSD & Patch Size Standard Deviation & ha \\
\hline & PSCov & Patch Size Coefficient of Variation & $\%$ \\
\hline \multirow[t]{4}{*}{ Shape } & LSI & Landscape Shape Index & - \\
\hline & MSI & Mean Shape Index & - \\
\hline & AWMSI & Area-Weighted Mean Shape Index & - \\
\hline & MPAR & Mean Perimeter-Area Ratio & $\mathrm{m} \mathrm{ha}^{-1}$ \\
\hline \multirow[t]{2}{*}{ Edge } & $\mathrm{TE}$ & Total Edge & $\mathrm{m}$ \\
\hline & ED & Edge Density & $\mathrm{m} \mathrm{ha}^{-1}$ \\
\hline Proximity & MNN & Mean Nearest-Neighbor Distance & $\mathrm{m}$ \\
\hline \multirow[t]{4}{*}{ Core area } & TCA & Total Core Area & ha \\
\hline & NCA & Number of Core Areas & - \\
\hline & $\mathrm{MCA}$ & Mean Core Area & ha \\
\hline & TCAI & Total Core Area Index & $\%$ \\
\hline
\end{tabular}

Functions in R language were developed for the calculation of the metrics based on the equations described by McGarigal and Marks (1995), using as input parameter the raster file containing the forest fragments. In order to perform the calculations, it was needed the igraph package (Csardi \& Nepusz, 2006) version 1.0.1, raster (Hijmans et al., 2016) version 2.5-8, rgdal (Bivand, Keitt, \& Rowlingson, 2016) version 1.2-4 and rgeos (Bivand \& Rundel, 2016) version 0.3-2.1 compatible with R version 3.3.0.

The metric calculations were performed for each size class of the fragments as well as for the fragments as a whole, without stratification, in order to obtain general results of the study area and thus enable the comparison among those. The central area metrics were calculated using different edge distances, being 20, 60, 100 and 140 meters based on the method of Juvanhol et al. (2011), and Pirovani et al. (2014), in order to analyze the different results obtained. 


\section{Results and Discussion}

The thematic mapping accuracy of the forest fragments in the sub-basin Arroio Jaquirana for the year 2016 was measured using the Kappa index, in which the value of 0.85 was obtained. In this way, the classification was categorized as "excellent" according to the scale proposed by Landis and Koch (1997). The forest fragments were divided into size classes as shown in Figure 2.

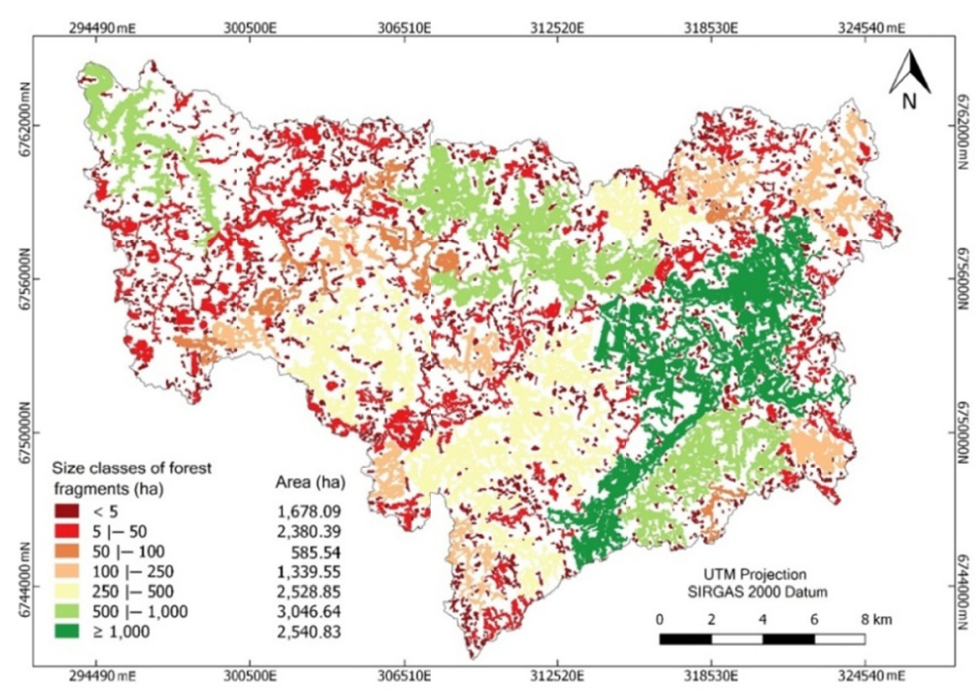

Figure 2. Espacialization of forest fragments in size classes in the sub-basin of Arroio Jaquirana, Rio Grande do Sul, Brazil

The results obtained for the calculated landscape metrics for the native forest fragments are set out in Table 4 . Calculations were performed separately for the seven size classes and also for the fragments as a whole.

The number of native forest fragments in the study area, in 2016, totaled 1,995, which covered 14,099.9 ha, equivalent to $34.01 \%$ of the total area of study. Most of the fragments belonged to the smaller size class, being well distributed in the study area. It was observed that with the increase of the fragments area decreased their number of occurrence, reaching 2 fragments in the class of larger size $(\geq 1,000 \mathrm{ha})$.

Table 4. Values of landscape ecology metrics for the forest fragments of the Arroio Jaquirana sub-basin, Rio Grande do Sul, Brazil

\begin{tabular}{|c|c|c|c|c|c|c|c|c|}
\hline \multirow{2}{*}{ Landscape Metrics } & \multicolumn{8}{|c|}{ Size of the fragments (ha) } \\
\hline & $1(<5)$ & $2(5 \mid-50)$ & $3(50 \mid-100)$ & $4(100 \mid-250)$ & $5(250 \mid-500)$ & $6(500 \mid-1000)$ & $7(\geq 1000)$ & $8(0$ to $\geq 1000)$ \\
\hline CA (ha) & $1,678.1$ & $2,380.4$ & 585.5 & $1,339.5$ & $2,528.8$ & $3,046.6$ & $2,540.8$ & $14,099.9$ \\
\hline NP & 1,804 & 160 & 9 & 9 & 7 & 4 & 2 & 1,995 \\
\hline MPS (ha) & 0.9 & 14.9 & 65.1 & 148.8 & 361.3 & 761.7 & $1,270.4$ & 7.1 \\
\hline MedPS (ha) & 0.5 & 9.8 & 61.5 & 130.8 & 329.0 & 777.9 & $1,270.4$ & 0.6 \\
\hline PSSD (ha) & 0.9 & 11.5 & 12.1 & 42.8 & 80.1 & 94.9 & 38.9 & 58.2 \\
\hline PSCov $(\%)$ & 102.82 & 77.40 & 18.68 & 28.76 & 22.18 & 12.46 & 3.06 & 823.71 \\
\hline LSI & 73.5 & 48.2 & 20.3 & 28.1 & 37.0 & 33.3 & 32.1 & 102.8 \\
\hline MSI & 1.8 & 3.7 & 6.7 & 9.4 & 14.0 & 16.6 & 22.7 & 2.1 \\
\hline AWMSI & 2.1 & 4.4 & 6.9 & 9.5 & 14.1 & 16.7 & 22.7 & 12.4 \\
\hline $\operatorname{MPAR}\left(\mathrm{m} \mathrm{ha}^{-1}\right)$ & 976.7 & 420.4 & 334.0 & 317.3 & 299.5 & 241.0 & 254.9 & 921.6 \\
\hline $\mathrm{TE}(\mathrm{m})$ & $1,204,409.0$ & $941,411.6$ & $196,648.5$ & $412,050.7$ & $744,639.9$ & $734,893.3$ & $648,102.8$ & $4,882,155.8$ \\
\hline $\mathrm{ED}\left(\mathrm{m} \mathrm{ha}^{-1}\right)$ & 29.0 & 22.7 & 4.7 & 9.9 & 17.9 & 17.7 & 15.6 & 117.7 \\
\hline $\mathrm{MNN}(\mathrm{m})$ & 103.6 & 244.3 & $2,568.3$ & $2,696.4$ & 566.9 & $3,022.7$ & 13.4 & 43.1 \\
\hline
\end{tabular}


The size class 1 , composed of fragments smaller than 5 ha, covered the largest number of fragments in the study area, a total of 1,804 , representing $93.43 \%$ of the total area. However, the area covered by the fragments belonging to classes 3 and 4 was smaller when compared to the others (Figure 3 ).

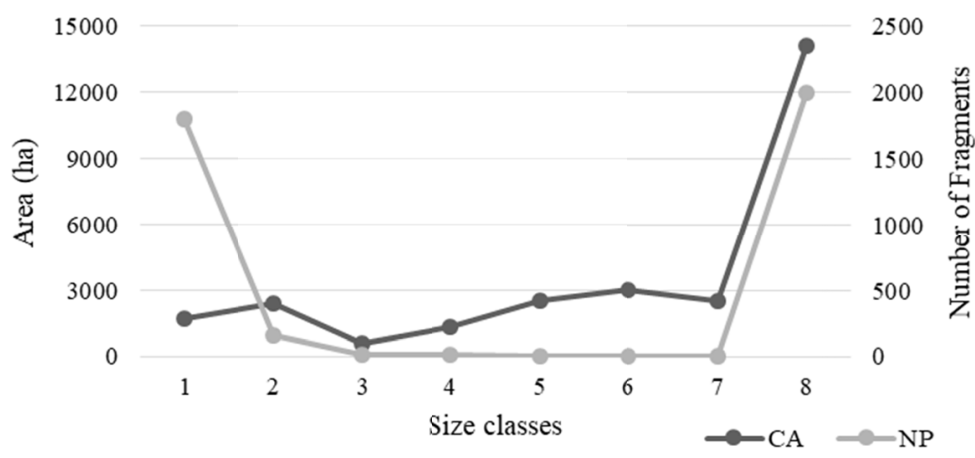

Figure 3. Relationship between the area (CA) and the number of forest fragments (NP) corresponding to each size class in the sub-basin of Arroio Jaquirana, Rio Grande do Sul, Brazil

The size class 2, on the other hand, comprised 160 fragments, being the second class with the largest number of fragments, however, this value is much lower than the one found in the first class, representing only $8.02 \%$ of the total fragments. The other size classes totalled 31 fragments, that is, $1.55 \%$ of the fragments belonged to classes 3 to 7 . Works performed by several authors corroborate with these found in this study. Juvanhol et al. (2011) evaluating areas of the Atlantic Forest biome, in the state of Espírito Santo, also found that most of the fragments belong to the smaller size class (less than 5 ha), covering $83 \%$ of the existing fragments. Hentz et al. (2015) also found a larger number of fragments with small areas, analyzing forest remnants of the Atlantic Forest in the Iguaçu river basin in Paraná.

Among the factors that directly influenced the formation of the large number of small fragments (less than 5 ha) in the study area, the Arroio Jaquirana sub-basin is agriculture and cattle raising, since the native forest region has been under high pressure caused by these land uses, causing vegetation suppression (Dessbesell, Pereira, Farias, Vogt, \& Welter, 2015). The largest fragments were found in sloping areas, which make agricultural implementation difficult, while in flat areas, which are favorable to agricultural plantations, are the remnants of forest with a higher degree of fragmentation, with a predominance of fragments occupying small areas.

The current situation of fragmentation in the study area, with a high number of fragments with up to 5 ha, becomes a worrisome factor. Since small fragments contain less species richness and often less species density, due to their influence on the edge effect (Laurence \& Vasconcelos, 2009). However, Forman and Godron (1986) have pointed out that small fragments can function as linking elements between large areas, in addition, they function as shelter for species that require unique environments that occur only in these areas, large fragments in turn are important for maintaining ecological processes and biodiversity.

With the results obtained for the mean patch size (MPS) of the fragments, it is noticed that it grows as the size class increases. Class 1 presented a mean area of 0.9 ha, indicating that a high number of fragments contained in the class presents an area smaller than 1 ha. In addition to this result, the median patch size (MedPS) was calculated, in which the value of 0.5 ha was obtained for the same size class, showing that half of the fragments of this class have an area smaller than 0.5 . In the same context, analyzing the fragments as a whole, the MedPS was 0.6 ha showing that half of the fragments (997 fragments) have an area inferior to 0.6 ha, indicating that the area of study is composed mostly by fragments occupying small areas, thus, the remnants have a low conservation index.

These results indicate that most of the fragments are in critical condition, due to the small areas occupied by them, since they tend to have a lower species richness. Thus, it is relevant to evaluate these fragments, in order to find management alternatives to preserve existing species, avoiding that these fragments will further reduce their areas.

By means of the index of form, it is possible to ascertain how vulnerable the fragments are to the influences of the external environment. The smallest size class, class 1, presented the highest shape index of the landscape 
$(\mathrm{LSI}=73.5)$, followed by the second class, with a value corresponding to 48.2 , the lowest value found in class 3 $(\mathrm{LSI}=20,3)$. The LSI measures the perimeter-area ratio for the landscape as a whole, as a function of a standard shape being equal to one when the landscape contains only a regularly shaped fragment (in the case of a raster the standard shape is a square). This, increases according to the greater disaggregation of the class indicating greater heterogeneity of the landscape (McGarigal \& Marks, 1995). Thus, it was noticed that class 1 obtained the highest value, due to the high number of fragments indicating a high degree of disaggregation.

The mean shape index indicates the degree of irregularity of the fragments. The lowest value was found in class 1 (MSI $=1.8$ ), indicating that the fragments with up to 5 ha have a more regular shape when compared to the other size classes, being the last class with the highest value, equivalent to 22.7. Pirovani et al. (2014), analyzed areas of Atlantic Forest, obtained values close to the one found in this study, with MSI equal to 1.85 for fragments smaller than $5 \mathrm{ha}$, presenting a more regular format of the other size classes adopted by the authors.

The area-weighted mean shape index (AWMSI) were higher than those observed for the MSI, however, the values did not show any significant differences, since the AWMSI calculated the shape index and weighted it in relation to the area of the fragments. Thus, larger values indicate that fragments of larger area present more irregular forms than the average fragments.

For the mean perimeter-area ratio (MPAR), the value of $976.7 \mathrm{~m} \mathrm{ha}^{-1}$ was obtained in the lowest class of fragments. The results obtained for this metric were directly proportional to the perimeter of the fragments; thus, indicate that high perimeter values lead to high MPAR values. The higher the perimeter, the greater the area exposed to the effects of the anthropic actions and the environmental conditions of the environment (Martins, Soares, Silva, \& Brites, 2002), leading to a greater edge effect and consequently an intensification of deleterious actions on the remaining ones (Oliveira \& Mattos, 2014). Thus, Colli et al. (2003) pointed out that the reduction of edge effects can be achieved by reducing the perimeter/area ratio of the fragments.

By means of the total edge (TE) and edge density (ED) metrics, it is possible to infer about the border effect in which the fragments are subject and the irregularity of them. Of the total border, 1,204,409.0 m represented class 1 , this value equivalent to border density of $29.0 \mathrm{~m} / \mathrm{ha}$. This class encompasses the smaller fragments, thus covering most of the fragments present in the study area, which resulted in a higher edge value, when compared to the other classes. Juvanhol et al. (2011) emphasize that in small fragments the transition between the matrix and the forest is quite abrupt, thus, an edge is developed exposing the forest to the effects of the external matrix, thus, causes microclimatic changes, which in turn will change the structure of vegetation and the composition of species.

Among the metrics that determine the isolation of fragments is that of the nearest neighbor, which is considered important, since it indicates the need for implementation or existence of connection elements (Vidolin, Biondi, \& Wandembruck, 2011). According to Table 4, the average distance of the mean nearest neighbor (MNN), obtained for each size class, presented the lowest value among the fragments of the largest size class (Class 7) totaling $13.4 \mathrm{~m}$. These fragments are located in sloping areas of the sub-basin, resulting in regions that are not suitable for agricultural cultivation. In this way, larger fragments located near each other were found, when compared to the other fragments of the study area.

Analyzing the fragments as a whole (Class 8), without stratifying by size classes, an average distance of $43.1 \mathrm{~m}$ was obtained, considered low compared to most size classes. This is due to the small fragments that soften the distance between the larger fragments, since they have high density and are well distributed in the study area. In this context, these fragments have an important ecological function, since they reduce the isolation of the larger fragments. Cemin, Perico, and Rampel (2009), when analyzing the distance of the nearest neighbor in deciduous forest areas in the Taquari Valley, Rio Grande do Sul, found a mean distance of $59.62 \mathrm{~m}$, close to that obtained in the present study, which totaled $43.1 \mathrm{~m}$. Pirovani et al. (2014) also found the shortest distance when analyzed the fragments as a whole. Thus, the authors emphasize the importance of considering smaller fragments as ecological trampolines, in addition reducing the distance between fragments of larger size. Silva and Souza (2014) point out that isolation reduces biological diversity as well as immigration rates. In this context, it is possible to perceive the importance that the smaller fragments present for the biodiversity maintenance, being able to be used as ecological corridors.

The central area is a better indication of the quality of forest fragments (McGarigaL \& Marks, 1995). The results for the central area metrics are shown in Table 5. 
Table 5. Values of the central area metrics for the forest fragments of the sub-basin Arroio Jaquirana, Rio Grande do Sul, Brazil

\begin{tabular}{|c|c|c|c|c|c|c|c|c|}
\hline \multirow{2}{*}{ Distance of Edge (m) } & \multicolumn{4}{|c|}{ Size Class $1(<5$ ha $)$} & \multicolumn{4}{|c|}{ Size Class $2(5 \mid-50$ ha $)$} \\
\hline & TCA & NCA & MCA & TCAI & TCA & NCA & MCA & TCAI \\
\hline 20 & 264.8 & 1,382 & 0.2 & 15.8 & 988.0 & 919 & 1.1 & 41.5 \\
\hline 60 & 0.7 & 14 & 0.1 & 0.5 & 123.8 & 133 & 0.9 & 5.2 \\
\hline 100 & 0.0 & 0 & 0.0 & 0.0 & 17.7 & 28 & 0.6 & 0.7 \\
\hline \multirow[t]{2}{*}{140} & 0.0 & 0 & 0.0 & 0.0 & 1.8 & 3 & 0.6 & 0.1 \\
\hline & \multicolumn{4}{|c|}{ Size Class 3 (50 $\mid-100$ ha $)$} & \multicolumn{4}{|c|}{ Size Class 4 (100 $\mid-250 \mathrm{ha})$} \\
\hline 20 & 288.4 & 154 & 1.9 & 49.2 & 705.3 & 334 & 2.1 & 52.6 \\
\hline 60 & 49.7 & 38 & 1.3 & 8.5 & 181.0 & 97 & 1.9 & 13.5 \\
\hline 100 & 8.8 & 6 & 1.5 & 1.5 & 70.5 & 25 & 2.8 & 5.3 \\
\hline \multirow[t]{2}{*}{140} & 0.5 & 2 & 0.0 & 0.0 & 32.3 & 4 & 8.1 & 2.4 \\
\hline & \multicolumn{4}{|c|}{ Size Class 5 (250 $\mid-500$ ha $)$} & \multicolumn{4}{|c|}{ Size Class $6(500-1000$ ha $)$} \\
\hline 20 & $1,372.4$ & 493 & 2.8 & 54.3 & $1,897.6$ & 443 & 4.3 & 62.3 \\
\hline 60 & 296.3 & 199 & 1.5 & 11.7 & 616.9 & 179 & 3.4 & 20.2 \\
\hline 100 & 63.3 & 54 & 1.2 & 2.5 & 210.7 & 62 & 3.4 & 6.9 \\
\hline \multirow[t]{2}{*}{140} & 11.9 & 12 & 1.0 & 0.5 & 57.5 & 30 & 1.9 & 1.9 \\
\hline & \multicolumn{4}{|c|}{ Size Class 7 ( $\geq 1000$ ha) } & & & & \\
\hline 20 & $1,897.6$ & 443 & 4.3 & 62.3 & & & & \\
\hline 60 & 616.9 & 179 & 3.4 & 20.2 & & & & \\
\hline 100 & 210.7 & 62 & 3.4 & 6.9 & & & & \\
\hline 140 & 57.5 & 30 & 1.9 & 1.9 & & & & \\
\hline
\end{tabular}

Analyzing the results it was possible to notice that for the $20 \mathrm{~m}$ border size class 1 presented a total of 1,382 fragments, which covered a total core area (TCA) of 264.8 ha, corresponding to $15.8 \%$ (total core area index-TCAI). In other words, this percentage of the total amount of fragments of this class is under the border effect in 20 meters. The second class with the highest number of fragments was 2, which covered a total of 919 fragments, corresponding to an area of 988.0 ha, equivalent to a central area index of $41.5 \%$.

With the increase of edge distance, the number of fragments and the area occupied by them decreased in all study size classes. The total core area (TCA) presented higher values at the edge of $20 \mathrm{~m}$, in this distance of edge, the larger size classes obtained larger central areas (Figure 4).

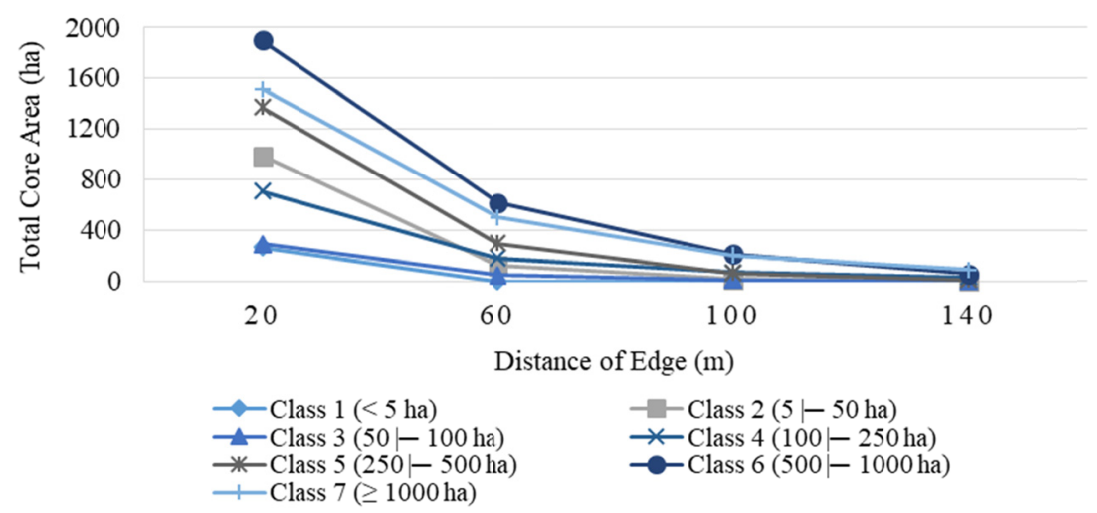

Figure 4. Behavior of the total core area (TCA) with increasing edge distance for the size classes of the forest fragments of the sub-basin Arroio Jaquirana, Rio Grande do Sul, Brazil

In size class 1 , few fragments present a central area when the $60 \mathrm{~m}$ edge was removed, while fragments with 100 and $140 \mathrm{~m}$ edge distances were not found, with total domination by edge effect. Thus, this result indicates that these fragments, which have an area smaller than 5 ha, are more susceptible to external effects. The same was 
obtained by Silva et al. (2015), in which the authors found null fragments, for those that presented areas lower than $5 \mathrm{ha}$, at border distances bigger than $80 \mathrm{~m}$.

Périco and Cemin (2006), when characterizing landscapes under the Atlantic Forest domain, observed that, over the years, there was decreasing in the central area of forest fragments, indicating an increasing in fragmentation. Ribeiro et al. (2009) when analyzing the Atlantic Forest as a whole observed that almost half of this one is under effect of edge inferior to $100 \mathrm{~m}$.

With this, it was observed, in the study area, that native forest fragments presented small central area when evaluating high edge distances. This factor leads to several negative consequences for the native species which inhabit these environments, since there are species intolerant to the effects caused by the edge, among them, the climatic changes and the occupation by exotic species.

In all size classes, with the exception of class $1(<5 \mathrm{ha})$, the number of fragments found for certain edge distances was higher than the number of fragments without edge removal. The highest values were verified in the distance of $20 \mathrm{~m}$, occurring decrease in the others. The same pattern was found by Pirovani et al. (2014), the author points out that this fact is due to the irregular shape of the fragments, which entails in several central areas. Thus, by analyzing the fragments in the study area it is possible to infer that these are composed of several elongated arranged forest areas, occupying small areas, which function as ecological corridors, between the larger areas.

In general, with the results obtained in this study it was verified that the areas of Atlantic Forest are highly fragmented with predominance of small fragments in which their central areas are exposed to the effects of the external matrix. Thus, with the analysis performed it is possible to verify the current situation of the native forest, serving as the basis for the proper management of the area.

\section{Conclusion}

The $\mathrm{R}$ program proved to be a promising and efficient tool for the manipulation of spatial data, which allowed performing the spatial analysis of forest fragments. By means of the ecology of the landscape, it can be concluded that most of the forest fragments in the sub-basin Arroio Jaquirana, under the domain of the Atlantic Forest biome, were small indicating the high degree of fragmentation of the local forest.

Thus, it is very important to establish measures to minimize edge effects and/or increase the connectivity between the fragments through ecological corridors using the smaller fragments, since they are well distributed in the study area and in large amount. It is also necessary to develop public policies and research to manage the region in order to preserve the remaining forest fragments, since the Atlantic Forest is quite devastated.

\section{Acknowledgements}

To the SINDITABACO for the availability of the images used in this work and to the Coordination of Improvement of Higher Level Personnel (CAPES) for the grant of a postgraduate scholarship.

\section{References}

Alvares, C. A., Stape, J. L., Sentelhas, P. C., Gonçalves, J. L. M., \& Sparovek G. (2014). Köppen's Climate Classification Map for Brazil. Meteorologische Zeitschrift, 22(6), 711-728. https://doi.org/10.1127/ 0941-2948/2013/0507

Bivand, R. S., Keitt, T., \& Rowlingson, B. (2016). Rgdal: Bindings for the Geospatial Data Abstraction Library (Version 1.2-4). Retrieved from https://cran.r-project.org/web/packages/rgdal/index.html

Bivand, R. S., \& Rundel, C. (2016). Rgeos: Interface to Geometry Engine (Version 0.3-21). Retrieved from https://cran.r-project.org/web/packages/rgeos/index.html

Brites, R. S., Bias, E. S., \& Rosa, A. N. C. R. (2012). Classificação por regiões. In P. R. Meneses, \& T. Almeida (Eds.), Introdução ao processamento de imagens de sensoriamento remoto (pp. 209-220). Brasília, Brasil: CNPQ.

Calegari, L., Martins, S. V., Gleriani, J. M., Silva, E., \& Busato, L. C. (2010). Dinâmica de fragmentos florestais no município de Carandaí, MG, para fins de restauração florestal. Revista Árvore, 34(5), 871-880. https://doi.org/10.1590/S0100-67622010000500012

Câmara, G., Souza, R. C. M., Freitas, U. M., Garrido, J., \& Mitsuo, F. (1996). Spring: Integrating remote sensing and GIS by object-oriented data modelling. Computers \& Graphics, 20(3), 395-403. https://doi.org/ 10.1016/0097-8493(96)00008-8 
Casajus, N. (2013). Analyses spatiales sous R. Canadá: Université du Québec à Rimouski, Département de Biologie, Chimie et Géographie. Retrieved from https://qcbs.ca/wiki/_media/gisonr.pdf

Cemin, G., Perico, E., \& Rampel, C. (2009). Composição e configuração da paisagem da sub-bacia do Arroio Jacaré, Vale do Taquari, RS, com ênfase nas áreas de florestas. Revista Árvore, 33(4), 705-711. https://doi.org/10.1590/S0100-67622009000400013

Colli, G. R., Accacio, G. M., Antonini, Y., Constantino, R., Franceschinelli, E. V., Laps, R. R., ... Wiederhecker, H. C. (2003). A fragmentação dos ecossistemas e a biodiversidade brasileira: Uma síntese. In D. M. Rambali, \& D. A. S. Oliveira (Eds.), Fragmentação de ecossistemas: Causas, efeitos sobre a biodiversidade e recomendações de políticas públicas. Brasília: $\mathrm{MMA} / \mathrm{SBF}$.

Congalton, R. G. (1991). A review of assessing the accuracy of classifications of remotely sensed data. Remote Sensing of Environment, 37(1), 35-46. https://doi.org/10.1016/0034-4257(91)90048-B

Congalton, R. G., \& Green, K. (1999). Assessing the Accuracy of Remotely Sensed Data: Principles and Practices. New York, NY: Lewis Publishers.

Csardi, G., \& Nepusz, T. (2006). The igraph software package for complex network research. InterJournal, Complex Systems 1695. Retrieved from http://igraph.org/r

Dessbesell, L., Pereira, R. S., Farias, J. A., Vogt, E. A., \& Welter, C. A. (2015). Classificação do uso e cobertura da terra a partir de imagens RapidEye para o município de segredo, RS, Brasil. Geografia, 40(2), 291-304.

Forman, R. T. T., \& Godron, M. (1986). Landscape Ecology. New York, NY: John Wilwy \& Sons.

Fundação SOS Mata Atlântica. (2015). Relatório Anual 2015. Retrieved from https://sosma.org.br/wp-content/ uploads/2016/08/RA_SOSMA_2015-Web.pdf

Happ, P. N., Feitosa, R. Q., Bentes, C., \& Farias, R. (2013). Um algoritmo de segmentação por crescimento de regiões para GPUS. Boletim de Ciências Geodésicas, 19(2), 208-226. https://doi.org/10.1590/S1982-2170 2013000200004

Hentz, A. M. K., Corte, A. P. D., Doubrawa, B., \& Sanquetta, C. R. (2015). Avaliação da fragmentação dos remanescentes florestais da bacia hidrográfica do rio Iguaçu, PR, Brasil. Enciclopédia Biosfera, 11(21), 2842-2858.

Hijmans, R. J., Etten, J. V., Cheng, J., Mattiuzzi, M., Summer, M., Greenberg, J. A., ... Ghosh, A. (2017). Raster: Geographic Data Analysis and Modeling (Version 2.5-8). Retrieved from https://cran.r-project.org/web/ packages/raster/index.html

Jenkins, C. N., Pimm, S. L., \& Joppa, L. N. (2013). Global patterns of terrestrial vertebrate diversity and conservation. PNAS, 110(28), 1-9. https://doi.org/10.1073/pnas.1302251110

Jung, M. (2016). LecoS-A python plugin for automated landscape ecology analysis. Ecological Informatics, 31, 18-21. https://doi.org/10.1016/j.ecoinf.2015.11.006

Juvanhol, R. S., Fiedler, N. C., Santos, A. R., Pirovani, D. B., Louzada, F. L. R. O., Dias, H. M., \& Tebaldi, A. L. C. (2011). Análise espacial de fragmentos florestais: Caso dos parques estaduais de Forno Grande e Pedra Azul, estado do Espírito Santo. Floresta e Ambiente, 14(4), 353-364. https://doi.org/10.4322/floram. 2011.055

Landis, J. R., \& Koch, G. G. (1997). The measurement of observer agreement for categorical data. Biometrics, 33(1), 159-174. https://doi.org/10.2307/2529310

Laurance, W. F. (2009). Conserving the hottest of the hotspots. Biological Conservation, 142(6), 1137. https://doi.org/10.1016/j.biocon.2008.10.011

Laurance, W. F., \& Vasconcelos, H. L. (2009). Consequências ecológicas da fragmentação florestal na Amazônia. Oecologia Brasiliensis, 13, 343-451. https://doi.org/10.4257/oeco.2009.1303.03

Lindenmayer, D. B., Hobbs, R. J., Montague-Drake, R., Alexandra, J., Bennett, A., Burgman, M., ... Zavaleta, E. (2008). A checklist for ecological management of landscapes for conservation. Ecology Letters, 11(1), 78-91. https://doi.org/10.1111/j.1461-0248.2007.01114.x

Lindenmayer, D. B., \& Fischer, J. (2006). Habitat Fragmentation and Landscape Change: An Ecological and Conservation Synthesis. Washington, DC: Island Press.

Mariota, P. (2015). Challenges and opportunities in harnessing satellite remote-sensing for biodiversity monitoring. Ecological Informartics, 30, 207-214. https://doi.org/10.1016/j.ecoinf.2015.08.006 
Martins, I. C. M., Soares, V. P., Silva, E., \& Brites, R. S. (2002). Diagnostico ambiental no contexto da paisagem de fragmentos florestais naturais "Ipucas" no município de Lagoa da Confusão, Tocantins. Revista Árvore, 26(3), 299-309. https://doi.org/10.1590/S0100-67622002000300005

Matos, F. A. R., Magnago, L. F. S., Gastauer, M., Carreiras, J. M. B., Simonelli, M., Meira-Neto, J. A. A., \& Edwards, D. P. (2017). Effects of landscape configuration and composition on phylogenetic diversity of trees in a highly fragmented tropical forest. Journal of Ecological, 105, 265-276. https://doi.org/10.1111/ $1365-2745.12661$

McGarigal, K., Marks, B. J. (1995). Fragstats: Spatial pattern analysis program for quantifying landscape structure. Portland: USDA Forest Service. https://doi.org/10.2737/PNW-GTR-351

Moreira, M. A., Barros, M. A., \& Rudorff, B. F. T. (2008). Geotecnologias no mapeamento da cultura do café em escala municipal. Sociedade \& Natureza, 20(1), 101-110. https://doi.org/10.1590/S1982-4513200800 0100007

Muenchen, R. A. (2011). R for SAS and SPSS Users (2nd ed.). New York, NY: Springer. https://doi.org/10.1007/ 978-1-4614-0685-3

Negrini, M., Higuchi, P., Silva, A. C., Spiazzi, F. R., Buzzi Junior, F., \& Vefago, M. B. (2014). Heterogeneidade florístico-estrutural do componente arbóreo em um sistema de fragmentos florestais no Planalto Sul catarinense. Revista Árvore, 38(5), 779-786. https://doi.org/10.1590/S0100-67622014000500002

Oliveira, F. F. G., \& Mattos, J. T. (2014). Análise ambiental de remanescentes do bioma Mata Atlântica no litoral sul do Rio Grande do Norte, NE do Brasil. Espaço e Tempo, 18(1), 165-183. https://doi.org/10.11606/ issn.2179-0892.geousp.2014.81095

Périco, E., \& Cemin, G. (2006). Caracterização da paisagem do município de Arvorezinha, RS, com ênfase na dinâmica dos fragmentos florestais, por meio de sistemas de informações geográficas (SIGs). Scientia Forestalis, 70, 09-21.

Pirovani, D. B., Silva, A. G., Santos, A. R., Cecílio, R. A., Gleriani, J. M., \& Martins, S. V. (2014). Análise especial de fragmentos florestais na Bacia do Rio Itapemirim, ES. Revista Árvore, 38(2), 271-281. https://doi.org/10.1590/S0100-67622014000200007

QGIS Development Team. (2016). QGIS Geographic Information System. Open Source Geospatial Foundation Project. Retrieved from https://qgis.org/en/site/

R Development Core Team. (2016). R: A Language and Environment for Statistical Computing. Vienna: R Foundation for Statistical Computing. Retrieved from https://r-project.org

Rambo, B. (1956). A fisionomia do Rio Grande do Sul (2nd ed.). Porto Alegre, RS: Selbach.

Ribeiro, M. C., Metzger, J. P., Martensen, A. C., Ponzoni, F. J., \& Hirota, M. M. (2009). The Brazilian Atlantic Forest: How much is left, and how is the remaining forest distributed: Implications for conservation. Biological Conservation, 142(6), 1141-1153. https://doi.org/10.1016/j.biocon.2009.02.021

Silva, M. S. F., \& Souza, R. M. (2014). Padrões espaciais de fragmentação florestal na Flona do Ibura, Sergipe. Mercator, 13(3), 121-137. https://doi.org/10.4215/RM2014.1303.0009

Silva, K. G., Santos, A. R., Silva, A. G., Peluzio, J. B. E., Fiedler, N. C., \& Zanetti, S. S. (2015). Análise da dinâmica espaço-temporal dos fragmentos florestais da sub-bacia hidrográfica do Rio Alegre, ES. Cerne, 21(2), 311-318. https://doi.org/10.1590/01047760201521021562

Silva, W. G., Metzger, J. P., Simões, S., \& Simonetti, C. (2007). Relief influence on the spatial distribution of the Atlantic Forest cover at the Ibiúna Plateau, SP. Brazilian Journal of Biology, 67(3), 403-411. https://doi.org/10.1590/S1519-69842007000300004

Skokanová, H., \& Eremiášová, R. (2013). Landscape functionality in protected and unprotected areas: Case studies from the Czech Republic. Ecological Informatics, 14, 71-74. https://doi.org/10.1016/j.ecoinf. 2012.11.007

Vidolin, G. P., Biondi, D., \& Wandembruck, A. (2011). Análise da estrutura da paisagem de um remanescente de floresta com araucária, Paraná, Brasil. Revista Árvore, 35(3), 515-525. https://doi.org/10.1590/S0100-67622 011000300014 


\section{Copyrights}

Copyright for this article is retained by the author(s), with first publication rights granted to the journal.

This is an open-access article distributed under the terms and conditions of the Creative Commons Attribution license (http://creativecommons.org/licenses/by/4.0/). 